\title{
Allosauroid (Theropoda, Tetanurae) remains from the Sierra Barrosa Formation (Middle Coniacian, Upper Cretaceous), Patagonia, Argentina
}

MATTIA ANTONIO BAIANO1,2,3

LEONARDO SEBASTIÁN FILIPPI

1. Área Laboratorio e Investigación, Museo Municipal "Ernesto Bachmann". Dr. Natali s/n, Q8311AZA Villa El Chocón, Neuquén, Argentina.

2. Consejo Nacional de Investigaciones Científicas y Técnicas (CONICET).

3. Universidad Nacional de Río Negro (UNRN). Isidro Lobo 516, 8332 General Roca, Río Negro, Argentina.

4. Museo Municipal Argentino Urquiza. Chos Malal 1277, Q8319BFA Rincón de los Sauces, Neuquén, Argentina.

Recibido: 2 de septiembre 2021 - Aceptado: 25 de octubre 2021 - Publicado: 26 de enero 2022

Para citar este artículo: Mattia Antonio Baiano \& Leonardo Sebastián Filippi (2022). Allosauroid (Theropoda, Tetanurae) remains from the Sierra Barrosa Formation (Middle Coniacian, Upper Cretaceous), Patagonia, Argentina. Publicación Electrónica de la Asociación Paleontológica Argentina 22 (1): 1-10.

Link a este artículo: http://dx.doi.org/10.5710/PEAPA.25.10.2021.396

()2022 Baiano and Filippi

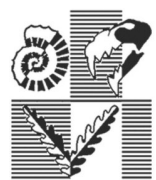

ISSN 2469-0228
Asociación Paleontológica Argentina

Maipú $6451^{\circ}$ piso, C1006ACG, Buenos Aires

República Argentina

Tel/Fax (54-11) 4326-7563

Web: www.apaleontologica.org.ar
Acceso Abierto Open Access

This work is licensed under CC BY-NC 4.0

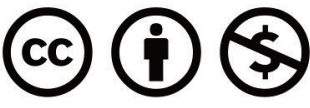




\title{
ALLOSAUROID (THEROPODA, TETANURAE) REMAINS FROM THE SIERRA BARROSA FORMATION (MIDDLE CONIACIAN, UPPER CRETACEOUS), PATAGONIA, ARGENTINA
}

\author{
MATTIA ANTONIO BAIANO 0,2,3 AND LEONARDO SEBASTIÁN FILIPPI ${ }^{4}$ \\ 1Área Laboratorio e Investigación, Museo Municipal "Ernesto Bachmann”. Dr. Natali s/n, Q8311AZA Villa El Chocón, Neuquén, Argentina. mbaiano@unrn.edu.ar \\ ${ }^{2}$ Consejo Nacional de Investigaciones Científicas y Técnicas (CONICET). \\ 3Universidad Nacional de Río Negro (UNRN). Isidro Lobo 516, 8332 General Roca, Río Negro, Argentina. \\ 4Museo Municipal Argentino Urquiza. Chos Malal 1277, (Q8319BFA), Rincón de los Sauces, Neuquén, Argentina. Isfilippi@gmail.com
}

MAB: https://orcid.org/0000-0003-0121-2139; LSF: https://orcid.org/0000-0003-0743-8294

\begin{abstract}
The Late Cretaceous theropod fauna of South America is composed of Abelisauridae, Noasauridae, Spinosauridae, Carcharodontosauridae, Megaraptora, and Coelurosauria. These groups include mostly small (Noasauridae and Coelurosauria) and medium- to large-sized taxa (Carcharodontosauridae, Abelisauridae, and Megaraptora). Some of these lineages are predominantly Gondwanic (Abelisauridae, Noasauridae, Carcharodontosauridae, Megaraptora) and poorly represented in Laurasian landmasses. Particularly, several theropods have been reported from Patagonia, known either due to distinct anatomical features or due to their high degree of preservation, such as Carnotaurus, Skorpiovenator, Giganotosaurus, Megaraptor, Alvarezsaurus, and Unenlagia. Here we describe a new incomplete tibia (MAU-PV-CM-653) from the Sierra Barrosa Formation (middle Coniacian, Upper Cretaceous), Patagonia, Argentina. MAU-PV-CM-653 shows an anteroposteriorly reduced cnemial crest that is strongly curved laterally. Finally, the tibia lacks a proximal extension of the fibular crest. These traits are reminiscent of tetanuran morphology and, together with the stratigraphic provenance of MAU-PV-CM-653, they allow us to assign it to an allosauroid theropod, thus improving the Allosauroidea global record for the middle Late Cretaceous.
\end{abstract}

Key words. Late Cretaceous. Neuquén Group. South America. Patagonia. Dinosauria. Allosauroidea. Tibia.

Resumen. RESTOS DE ALLOSAUROIDEO (THEROPODA, TETANURAE) DE LA FORMACIÓN SIERRA BARROSA (CONIACIANO MEDIO, CRETÁCICO SUPERIOR), PATAGONIA, ARGENTINA. La fauna de terópodos del Cretácico Tardío de América del Sur está compuesta por Abelisauridae, Noasauridae, Carcharodontosauridae, Spinosauridae, Megaraptora y Coelurosauria. Estos grupos incluyen mayormente taxones de pequeño (Noasauridae y Coelurosauria) y de mediano a gran tamaño (Abelisauridae, Carcharodontosauridae y Megaraptora). Algunos de estos linajes son predominantemente gondwánicos (Abelisauridae, Noasauridae, Carcharodontosauridae, Megaraptora) y poco representados en los continentes laurásicos. Particularmente, distintos terópodos han sido reportados desde la Patagonia, conocidos o por sus distintivas características anatómicas o por su grado de preservación, tales como Carnotaurus, Skorpiovenator, Giganotosaurus, Megaraptor, Alvarezsaurus y Unenlagia. Aquí describimos una nueva tibia incompleta (MAU-PV-CM-653) proveniente de la Formación Sierra Barrosa (Coniaciano medio, Cretácico Superior), Patagonia, Argentina. MAU-PV-CM-653 muestra una cresta cnemial reducida anteroposteriormente, que está fuertemente curvada lateralmente. Finalmente, la tibia carece de una extensión proximal de la cresta fibular. Estos rasgos hacen recordar una morfología de tetanuro y, junto con la procedencia estratigráfica de MAU-PV-CM-653, nos permite asignarla a un terópodo allosauroideo, y por ende mejorar el registro global de Allosauroidea para la parte media del Cretácico Tardío.

Palabras clave. Cretácico Superior. Grupo Neuquén. América del Sur. Patagonia. Dinosauria. Allosauroidea. Tibia.

THE CRETACEOUs South American theropod record spans all major internal taxa (e.g., Ceratosauria, Allosauroidea, Coelurosauria), and is represented by small, medium, and large-sized specimens (e.g., Carrano \& Sampson, 2008; Carrano et al., 2012; Novas et al., 2013). In particular, this region is the most abundant fossil area compared to other Gondwanan provinces, due to the strong increase in the
South American fossil record from the Cenomanian (Late Cretaceous) onward. The abundance of remains of some groups of theropods such as Abelisauridae, Megaraptora, and Maniraptora in the Argentine Patagonia is remarkable, with a large number of nominated taxa, some of which are distinguished by their high degree of conservation (e.g., Novas et al., 2013). 
The Neuquén Group is the principal lithostratigraphic unit regarding the theropod fossil record in northern Patagonia (e.g., Leanza et al., 2004; Garrido, 2010), and it is subdivided in nine formations that mainly encompass the Upper Cretaceous (middle Cenomanian-middle Campanian) (Garrido, 2010). However, theropod remains are scarce from the Río Neuquén Subgroup (Portezuelo, Los Bastos, Sierra Barrosa and Plottier formations; middle Turonian-lower Santonian), except for the Portezuelo Formation (Novas, 1997, 1998; Novas \& Puerta, 1997; Calvo et al., 2004a; Novas \& Pol, 2005). This paucity of theropods mainly affects the allosauroid record, since only two specimens have been recorded from the middle Late Cretaceous (Coria \& Currie, 2016; Porfiri et al., 2018). However, when we take into account the global allosauroid record (excepting Argentina), this paucity is even worse, since no middle Late Cretaceous (Coniacian-Santonian) specimens have been discovered anywhere else up to now. Here, we report a new tetanuran theropod partial tibia from the Sierra Barrosa Formation (middle Coniacian, Upper Cretaceous) (Fig. 1) that we refer to Allosauroidea based on several features of its morphology and, tentatively, to Megaraptora if we consider its stratigraphic provenance.

Institutional acronyms. MAU, Museo Municipal Argentino Urquiza, Rincón de los Sauces, Argentina; MB, Museum für Naturkunde, Humboldt-Universität zu Berlin, Germany; MCF, Museo Municipal Carmen Funes, Plaza Huincul, Argentina; MCT, Museu de Ciências da Terra do Departamento Nacional de Produção Mineral, Rio de Janeiro, Brazil; MPCA, Museo Provincial Carlos Ameghino, Cipolletti, Argentina; MPEF, Museo Paleontológico Egidio Feruglio, Trelew, Argentina; MUC, Museo Universidad Nacional del Comahue, Neuquén, Argentina; UNPSJB, Universidad Nacional de la Patagonia San Juan Bosco, Comodoro Rivadavia, Argentina; USNM, National Museum of Natural History, Smithsonian Institution, Washington, USA.

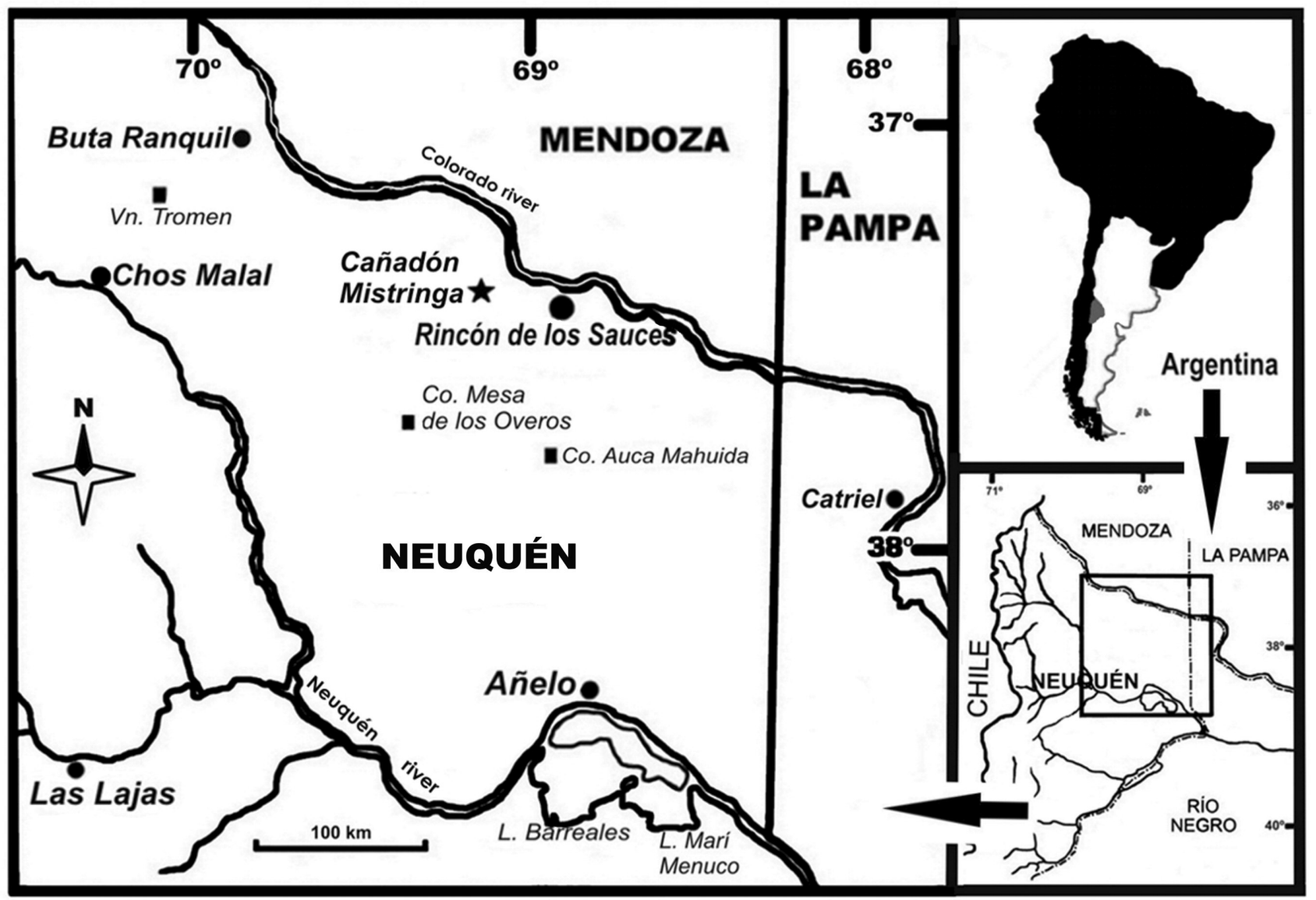

Figure 1. Locality map showing where the specimen MAU-PV-CM-653 was found, indicated by the black star. 


\begin{tabular}{lllll}
\hline \hline \multicolumn{2}{l}{ TABLE 1 - Measurements (in cm) of the tibia MAU-PV-CM-653 } & \\
\hline Proximodistal Length & $\begin{array}{l}\text { Proximodistal Length } \\
\text { of Cnemial Crest }\end{array}$ & $\begin{array}{l}\text { Anteroposterior Length } \\
\text { of Proximal Surface }\end{array}$ & $\begin{array}{l}\text { Anteroposterior Length } \\
\text { of Cnemial Crest }\end{array}$ & $\begin{array}{l}\text { Mediolateral Width of } \\
\text { Proximal Posterior Rim }\end{array}$ \\
\hline $11.5^{*}$ & 6.6 & 12.7 & 4.3 & 6.8 \\
\hline
\end{tabular}

*Asterisk indicates incomplete measurements due to missing bone.

\section{SYSTEMATIC PALEONTOLOGY}

\author{
DINOSAURIA Owen, 1842 \\ THEROPODA Marsh, 1881 \\ TETANURAE Gauthier, 1986 \\ ALLOSAUROIDEA (Marsh, 1878) \\ ALLOSAUROIDEA indet.
}

Figures 2 and 3.1

Specimen. MAU-PV-CM-653, proximal end of the left tibia (Tab. 1).

Geographic occurrence. MAU-PV-CM-653 was found at Cañadón Mistringa locality, southwest of Rincón de los Sauces city, Pehuenches Department, Neuquén Province, Argentina (Fig. 1).

Stratigraphic occurrence. The fossil-bearing strata are attributed to the Sierra Barrosa Formation (Coniacian, Upper Cretaceous), Neuquén Group (Garrido, 2010), Neuquén Basin.

Description. MAU-PV-CM-653 corresponds to the proximal end of the left tibia, including the articular surface, the posterior condyles, and the cnemial crest. However, the specimen lacks the rest of the diaphysis, including the crista fibularis and the distal articular end. In proximal view (Fig. 2.1), the articular surface has a comma shaped outline. The proximal condyles are well defined and separated by a shallow intercondylar sulcus. The medial condyle shows a teardrop outline, whereas the lateral condyle is oval in outline, with an anteroposteriorly oriented major axis. Furthermore, the medial condyle is anteroposteriorly longer and more posteriorly projected than the lateral one. Anterior to the articular condyles there is a depression that is probably where the femoral tibial condyle articulated. The cnemial crest is anteroposteriorly reduced and is strongly curved laterally. In fact, the anterior rim of the cnemial crest is positioned at 90 degrees with respect to the main axis of the proximal surface. The medial rim is convex due to the lateral curvature of the cnemial crest. The lateral rim is sinusoidal, since the section that corresponds to the lateral condyle is slightly convex whereas the section that corresponds to the cnemial crest is concave. The lateral condyle is separated from the cnemial crest by a deep incisura tibialis. However, the lateral condyle of MAU-PV-CM-653 lacks a distally directed anterolateral process. The posterior rim is $\mathrm{w}$-shaped and is obliquely oriented relative to the mediolateral axis.

In medial view (Fig. 2.2), the preserved portion of the tibia is triangular in outline. The dorsal rim is almost straight, only bowing ventrally at the posterior end. In this view, the cnemial crest is horizontal and does not exceed the articular surface proximally. Near the posterodorsal corner, there is a triangular depression with a rugose surface where the muscles flexor tibialis internus 3 (FTI3) and flexor tibialis externus (FTE) (Carrano \& Hutchinson, 2002) were probably inserted. The surface is slightly concave near the anterior border of the cnemial crest.

In lateral view (Fig. 2.3), the medial condyle is proximally higher and posteriorly deeper than the lateral condyle, resulting in a laterodistally inclined proximal surface. The lateral condyle ends distally with a marked step. The lateral fossa of the cnemial crest is anteroposteriorly narrow with a finger-like outline and its major axis is anteroproximallyposterodistally oriented. The anterior rim of the cnemial crest is slightly convex and bears a rugose bump at the proximal end, where the muscles ambiens (AMB), femorotibialis (FMT), and iliotibiales 1-3 (IT 1-3) would have been inserted (Carrano \& Hutchinson, 2002). The fibular crest cannot be observed because of the poor preservation of the tibial 
(1)
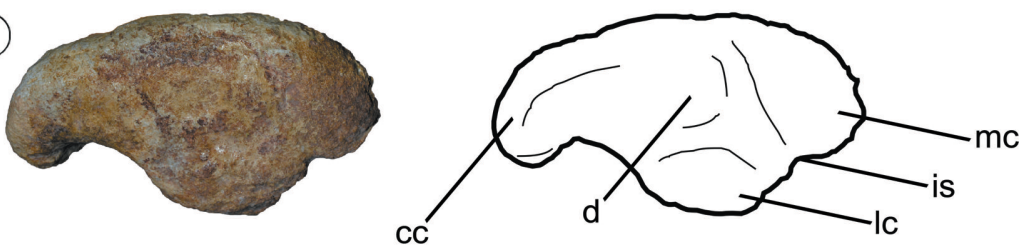

(2)
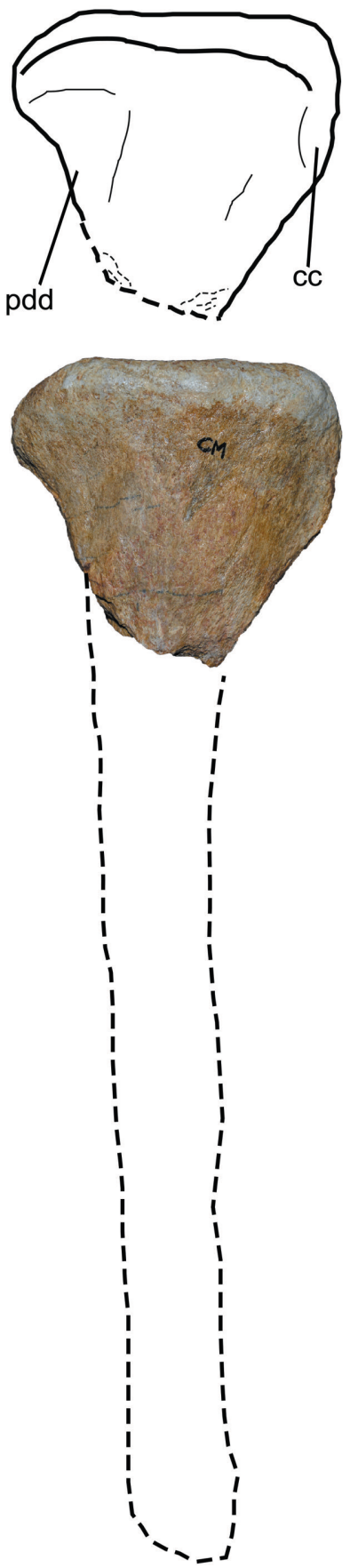

(3)
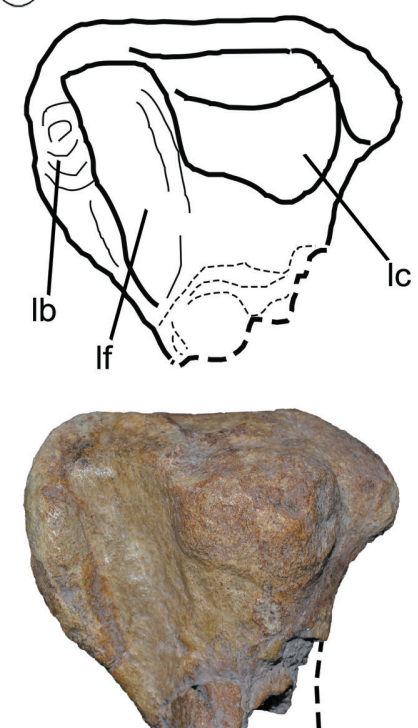

$(4)$
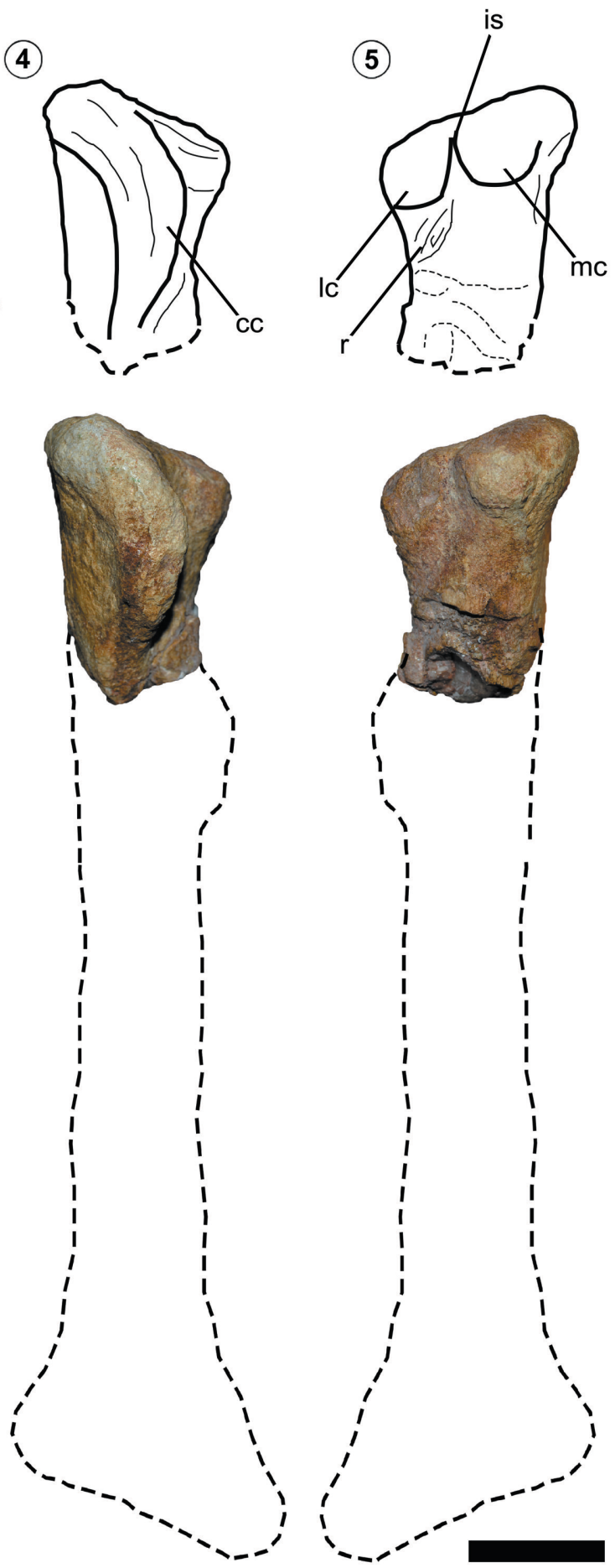

Figure 2. Allosauroidea indet. MAU-PV-CM-653. Tibia in 1, proximal; 2, medial; 3 , lateral; 4, anterior; and 5, posterior views. Abbreviations: cc, cnemial crest; d, depression; is, intercondylar sulcus; lb, lateral bump; lc, lateral condyle; If, lateral fossa; mc, medial condyle; pdd, posterodorsal depression; $r$, rugosity. Scale bar $=5 \mathrm{~cm}$. 
shaft. However, in the fragment of tibia presented, the fibular crest does not extend proximally or anteroproximally onto the lateral surface of the cnemial crest.

In anterior view (Fig. 2.4), the cnemial crest is laterally directed with a thick proximal end that narrows towards the distal end. On the medial part, the shallow medial depression is visible, delimited proximally and anteriorly by a stout ridge.

In posterior view (Fig. 2.5), the proximal rim is laterodistally oriented. The medial condyle is rounded and ends distally with a convex step. The lateral condyle has a rugose surface and is rectangular in shape, with the major axis mediolaterally positioned. The intercondylar sulcus is deep and distally to it there is a rugose oval area where soft tissue was probably inserted (possibly the muscle flexor tibialis internus 1, FTI1; Carrano \& Hutchinson, 2002). Although the tibial shaft has been almost completely lost, the preserved fragment shows a lateral bowing of the element.

\section{DISCUSSION AND CONCLUSIONS}

The MAU-PV-CM-653 tibia shows a posteriorly positioned medial condyle, a condition present more markedly in Neovenator, Orkoraptor, and in the indeterminate tetanuran MB.R.1763, but different from the condition present in Australovenator, Fukuiraptor, Murusraptor, Phuwiangvenator, and Vayuraptor, in which both proximal condyles reach roughly the same distance posteriorly (Azuma \& Currie, 2000; Rauhut, 2005a; Brusatte et al., 2008; Novas et al., 2008; White et al., 2013; Coria \& Currie, 2016; Samathi et al., 2019) (Fig. 3.1, 3.6, 3.8). However, the rounded posterior end of the medial condyle of MAU-PV-CM-653 differs from the triangular posterior end of Neovenator and of the indeterminate tetanuran MB.R.1763 (Fig. 3.1, 3.6). MAU-PV-CM653 differs from Allosaurus, Neovenator, Australovenator, Fukuiraptor, Murusraptor, Phuwiangvenator, Vayuraptor, and the tetanuran MB.R.1763 since it lacks the anterolateral projection of the lateral condyle present in the other mentioned taxa (Madsen, 1976; Azuma \& Currie, 2000; Rauhut, 2005a; Brusatte et al., 2008; White et al., 2013; Coria \& Currie, 2016; Samathi et al., 2019) (Fig. 3.1, 3.6, 3.8). In the same way, the absence of a ventrally oriented process of the lateral condyle observed in MAU-PV-CM-653 is shared with several tetanurans (e.g., Torvosaurus, Allosaurus, Sinraptor,
Fukuiraptor, Murusraptor, Orkoraptor, Vayuraptor; Madsen, 1976; Britt, 1991; Currie \& Zhao, 1993; Azuma \& Currie, 2000; Novas et al., 2008; Coria \& Currie, 2016; Samathi et al., 2019) (Fig. 3.1, 3.4, 3.7), but differs from Neovenator, Australovenator, Tyrannosaurus, Phuwiangvenator, and the indeterminate tetanuran MB.R.1763, that have a conspicuous ventrally directed process (Brochu, 2003; Rauhut, 2005a; Brusatte et al., 2008; White et al., 2013; Samathi et al., 2019) (Fig. 3.5-6, 3.8).

The anteroposteriorly reduced and strongly laterally curved cnemial crest of the MAU-PV-CM-653 tibia is a feature that is also observed in several large (e.g., Allosaurus, Sinraptor, Murusraptor, Tyrannosaurus; Madsen, 1976; Currie \& Zhao, 1993; Brochu, 2003; Coria \& Currie, 2016) and small-sized tetanurans (MB.R.1763; Rauhut, 2005a) (Fig. 3.1, 3.4-5), but that differs from the more open and more anteroposteriorly developed cnemial crest of the tibiae of non-averostran theropods (e.g., Dilophosaurus; Marsh \& Rowe, 2020), ceratosaurs (e.g., Ceratosaurus, Eoabelisaurus, Velocisaurus, Quilmesaurus, Xenotarsosaurus, Genusaurus, Aucasaurus; Gilmore, 1920; Martínez et al., 1986; Accarie et al., 1995; Madsen \& Welles, 2000; Coria, 2001; Coria et al., 2002; Pol \& Rauhut, 2012; Ibiricu et al., 2021; MCF-PVPH236; MPCA-PV-100; MPEF PV 3990; MUCPV-41; UNPSJBPV 184) and basal tetanurans (e.g., Piatnitzkysaurus; Rauhut, 2005b) (Fig. 3.1-3.3). The extension of the cnemial crest of MAU-PV-CM-653 is reduced when compared with Aerosteon (Aranciaga Rolando et al., 2021) and Australovenator (White et al., 2013), but similar to the development observed in Phuwiangvenator (Samathi et al., 2019). Moreover, MAU-PVCM-653 shows a cnemial crest almost horizontally projected in lateral view, as in the Murusraptor tibia but unlike the dorsally directed crest of Aerosteon. The lack of a proximal and an anteroproximal extension of the fibular crest onto the lateral cnemial crest and the absence of a connection between the fibular crest and the proximal rim observed in MAU-PV-CM-653 is a condition shared with tetanuran theropods (e.g., Allosaurus, Sinraptor, Murusraptor, Tyrannosaurus; Madsen, 1976; Currie \& Zhao, 1993; Brochu, 2003; MCF-PVPH-411) (Fig. 3.1, 3.4-5, 3.7). Whereas, coelophysoids and ceratosaurs have a fibular crest strongly developed, both proximally and anteroproximally, reaching the proximal rim (e.g., Ceratosaurus, Quilmesaurus, Ekrixinatosaurus, 
Aucasaurus; Madsen \& Welles, 2000; Rauhut, 2003; Calvo et al., 2004b; MCF-PVPH-236; MPCA-PV-100; MUCPV-294) (Fig. 3.2-3.3). The bump where muscles ambiens, femorotibialis, and iliotibiales 1-3 would have been inserted is less developed than the one observed in several ceratosaurs (e.g., Ceratosaurus, Eoabelisaurus, Xenotarsosaurus, Aucasaurus; Madsen \& Welles, 2000; MCF-PVPH-236; MPEF PV 3990; UNPSJB-PV 184), some megaraptorans (Australovenator, Murusraptor; White et al., 2013; Coria \& Currie, 2016), and large tetanurans (e.g., Allosaurus, Asfaltovenator, Torvosaurus, Tyrannosaurus; Madsen, 1976; Britt, 1991; Brochu, 2003; Rauhut \& Pol, 2019). The posterior intercondylar sulcus in MAU-PV-CM653 as well as in Australovenator (White et al., 2013) and Phuwiangvenator (Samathi et al., 2019), is shallower than the intercondylar sulcus of Murusraptor (MCF-PVPH-411). The posterior rugose area distal to the intercondylar sulcus is well marked, as in an indeterminate abelisauroid from Brazil (Abelisauroidea indet. MCT 1783-R; Machado et al., 2013). The posterior morphology of both condyles differs from the triangular medial condyle and the rounded lateral condyle observed in several ceratosaurs (e.g., Aucasaurus, Abelisauroidea indet. MCT 1783-R; Machado et al., 2013; MCF-PVPH-236).

Taxa belonging to several theropod clades have been discovered in the cretaceous layers from Patagonia (e.g., Coria, 2007; Novas, 2009; Novas et al., 2013), thus yielding the most comprehensive fossil record from Gondwana (Novas et al., 2013). The affinity of MAU-PV-CM-653 with Patagonian tetanurans, and the marked differences between this specimen and all known ceratosaur tibiae means it probably belonged to some tetanuran group (Megalosauroidea, Allosauroidea, or Coelurosauria; Rauhut et al., 2016). South American megalosauroid remains are mainly from Brazil, where several spinosaurid taxa have been discovered (e.g., Kellner et al., 2011; Carrano et al., 2012). In contrast, only a few isolated teeth have been reported from Patagonia (Canudo et al., 2004; Canale et al., 2017). Moreover, Megalosauroidea is a clade distributed mainly in the Jurassic (Megalosauridae; Rauhut et al., 2016) and throughout the Early Cretaceous up to the Cenomanian (Spinosauridae; Kellner et al., 2011; Malafaia et al., 2020a, 2020b). The Allosauroidea fossil record from the Late Cretaceous of Patagonia is mainly composed of carcharodontosaurian taxa, although carchar- odontosaurids disappeared globally after the Turonian (e.g., Canale et al., 2009; Delcourt \& Grillo, 2018), with the last presence of this family documented in Asia (Brusatte et al., 2009). However, a possible non-Carcharodontosauria allosauroid has been reported from the late Turonian-early Coniacian of Patagonia (Paulina Carabajal \& Coria, 2015). Carcharodontosauria also includes megaraptorans (Benson et al., 2010), extending the biochron of this lineage until the Maastrichtian (Novas et al., 2008; Méndez et al., 2012). Finally, Patagonian coelurosaurs are generally smaller sized theropods, some of them recovered as basal forms within Coelurosauria and others recovered deeply nested within Paraves (e.g., Novas et al., 2013; Motta et al., 2020). Interestingly, an alternative scenario proposes Megaraptora as a member of Tyrannosauroidea (Novas et al., 2013; Porfiri et al., 2014; Aranciaga Rolando et al., 2019), which implies a re-evaluation of Tetanurae internal relationships.

Taking into account the morphology of MAU-PV-CM653, plus the stratigraphic and geographic data from the records of some tetanuran clades (e.g., Megalosauroidea, Tyrannosauroidea), we assign it to Tetanurae, possibly to a less inclusive allosauroid group such as Megaraptora. The allosauroid record is globally scarce after the Turonian age, since it only includes megaraptoran taxa and several postCenomanian carcharodontosaurid teeth that have been reevaluated as belonging to Abelisauridae (see Canale et al., 2009 and references therein). From Argentina proceed the Cenomanian-Turonian Aoniraptor and two unnamed specimens (Motta et al., 2016; Lamanna et al., 2020), the late Turonian-early Coniacian Megaraptor namunhuaiquii (Novas, 1998; Porfiri et al., 2014), the middle Coniacian Murusraptor barrosaensis (Coria \& Currie, 2016), and the Santonian Tratayenia rosalesi (Porfiri et al., 2018). From the Campanian of Argentina, Aerosteon riocoloradensis (Sereno et al., 2008), Orkoraptor burkei (Novas et al., 2008), and several recently described unnamed megaraptorans (e.g., Novas et al., 2019; Ibiricu et al., 2020) have been reported. In contrast, from Brazil, only an indeterminate specimen has been communicated (Martinelli et al., 2013). For the Maastrichtian, the Allosauroidea record is also represented uniquely by megaraptorans known from Argentina and Brazil (Méndez et al., 2012; Casal et al., 2019). With the exception of the Argentine and Brazilian specimens for the Coniacian- 
Maastrichtian period, no other allosauroid dinosaurs are known globally. When the middle Late Cretaceous (ConiacianSantonian) is considered, only two taxa, i.e., Murusraptor and Tratayenia, and one specimen, MAU-PV-CM-653, are known.

Despite the incompleteness of MAU-PV-CM-653 and the lack of the peculiar traits that characterize the Late Cretaceous allosauroids of South America, this specimen could represent a new theropod taxon. In this case, the finding presented here increases the theropod fauna for the Sierra Barrosa Formation that currently only includes the megaraptorid Murusraptor barrosaensis (Coria \& Currie, 2016). The morphology of MAU-PV-CM-653 also differs from the tibia of Aerosteon riocoloradensis (Sereno et al., 2008) that was recovered in the same geographical area but in a different stratigraphic horizon (Anacleto Formation,
(1)
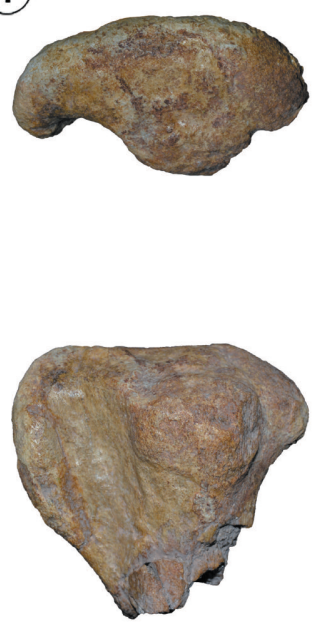

(5)

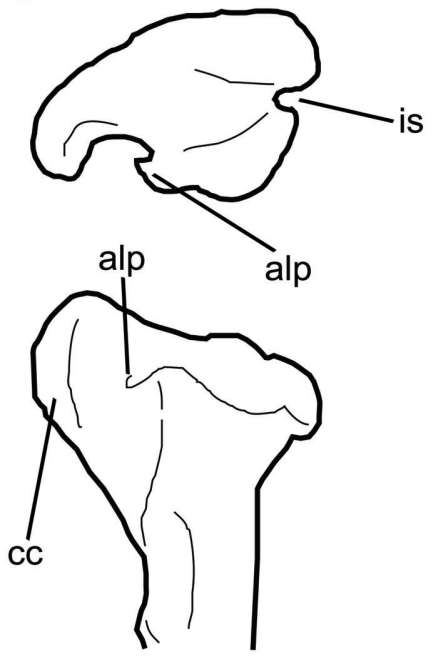

(2)

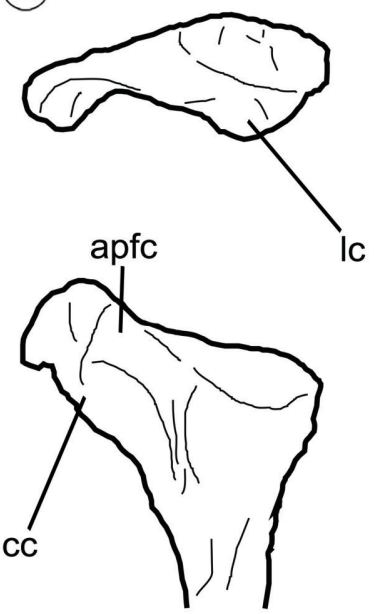

(3)
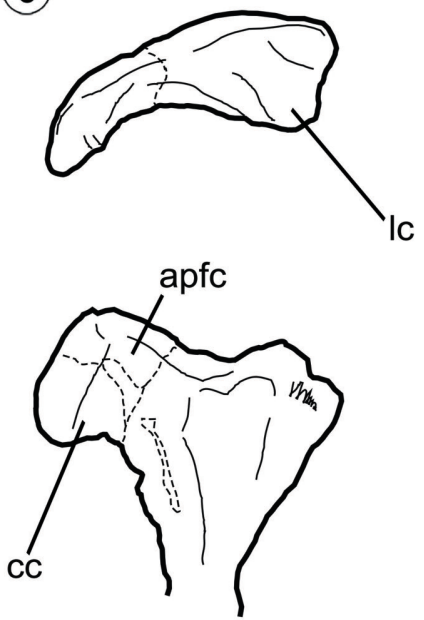

(4)
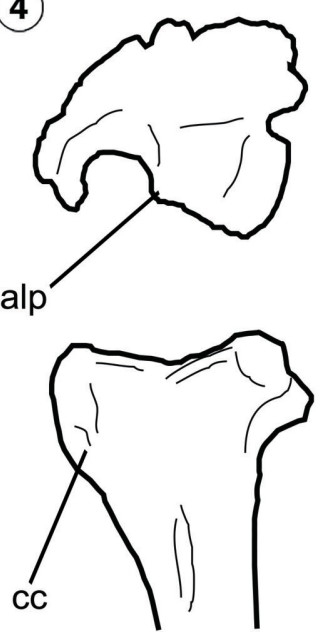

(6)
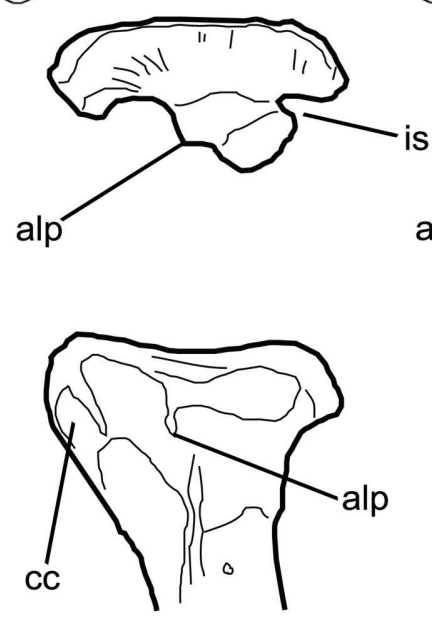

(7)
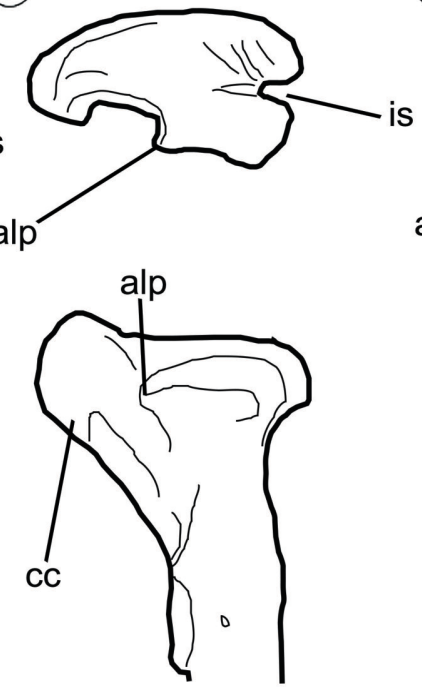

(8)
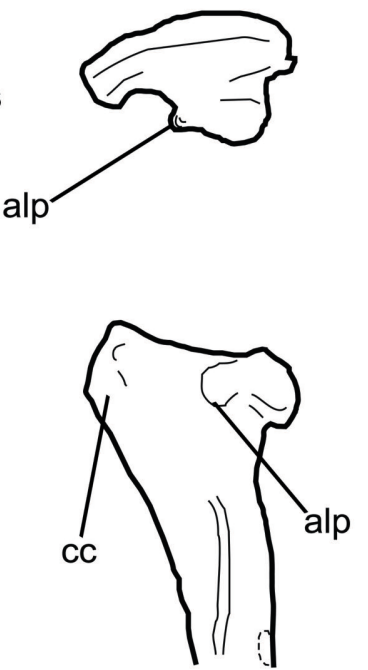

Figure 3. Comparison of theropod tibiae in proximal (top) and lateral (bottom) views. 1, Allosauroidea indet., MAU-PV-CM-653; 2, Ceratosaurus nasicornis (USNM 4735); 3, Quilmesaurus curriei (MPCA-PV-100; reversed); 4, Murusraptor barrosaensis (MCF-PVPH-411; reversed); 5, Tyrannosaurus rex (after Brochu, 2003); 6, Neovenator salerii (after Brusatte et al., 2008); 7, Allosaurus fragilis (after Madsen, 1976); and 8, Australovenator wintonensis (after White et al., 2013). Abbreviations: alp, anterolateral process; apfc, anteroproximal extension of the fibular crest; cc, cnemial crest; is, intercondylar sulcus; Ic, lateral condyle. Image not to scale. 
lower Campanian). Moreover, the allosauroid fossil record from the Coniacian to the Santonian is globally scarce, with some exceptions in South America (e.g., Coria \& Currie, 2016; Porfiri et al., 2018). Therefore, we consider MAU-PV-CM653 important to fill the paucity of this clade in the middle Late Cretaceous.

\section{ACKNOWLEDGMENTS}

We are thankful to S. Palomo, technician of the Museo Municipal Argentino Urquiza (MAU), who found the specimen MAU-PV-CM653. We are also grateful to the Municipalidad de Rincón de los Sauces for the logistical support provided during fieldwork. We are grateful to CONICET, Universidad Nacional de Río Negro (UNRN), and Municipalidad de Plaza Huincul for institutional support. We thank $A$. Méndez, an anonymous reviewer and PE-APA editorial board for their detailed comments and suggestions, which greatly improved the manuscript. L. Herbert (lucilaherbert@gmail.com) assisted with English editing. We also thank A. Méndez for providing us with the photographs of the Aerosteon tibia.

\section{REFERENCES}

Accarie, H., Beaudoin, B., Dejax, J., Friès, G., Michard, J. G., \& Taquet, P. (1995). Discovery of a new Theropod dinosaur (Genusaurus sisteronis n.g., n. sp.) in the marine Albian of Sisteron (Alpes de Haute-Provence, France) and the extension into the Lower Cretaceous of the Ceratosaur lineage. Comptes Rendus-Academie des Sciences, Paris serie 2 Sciences de la Terre et des Planetes, fascicule $A, 320,327-334$.

Aranciaga Rolando, M. A., Méndez, A., Canale, J. I., \& Novas, F. E. (2021). Osteology of Aerosteon riocoloradensis (Sereno et al. 2008) a large megaraptoran (Dinosauria, Theropoda) from the Upper Cretaceous of Argentina. Historical Biology, DOI: 10.1080/ 08912963.2021 .1910816

Aranciaga Rolando, M. A., Novas, F. E., \& Agnolín, F. L. (2019). A reanalysis of Murusraptor barrosaensis Coria \& Currie (2016) affords new evidence about the phylogenetical relationships of Megaraptora. Cretaceous Research, 99, 104-127.

Azuma, Y., \& Currie, P. J. (2000). A new carnosaur (Dinosauria, Theropoda) from the Lower Cretaceous of Japan. Canadian Journal of Earth Sciences, 37(12), 1735-1753.

Benson, R. B., Carrano, M. T., \& Brusatte, S. L. (2010). A new clade of archaic large-bodied predatory dinosaurs (Theropoda, Allosauroidea) that survived to the latest Mesozoic. Naturwissenschaften, 97(1), 71-78.

Britt, B. B. (1991). Theropods of Dry Mesa Quarry (Morrison Formation, late Jurassic), Colorado, with emphasis on the osteology of Torvosaurus tanneri. Brigham Young University Geology Studies, 37, $1-72$.

Brochu, C. A. (2003). Osteology of Tyrannosaurus rex: insights from a nearly complete skeleton and high-resolution computed tomographic analysis of the skull. Journal of Vertebrate Paleontology, 22(4), 1-138.

Brusatte, S. L., Benson, R. B. J., Chure, D. J., Xu, X., Sullivan, C., \& Hone, D. W. (2009). The first definitive carcharodontosaurid (Dinosauria, Theropoda) from Asia and the delayed ascent of tyrannosaurids. Naturwissenschaften, 96(9), 1051-1058.

Brusatte, S. L., Benson, R. B. J., \& Hutt, S. (2008). The osteology of Neovenator salerii (Dinosauria, Theropoda) from the Wealden
Group (Barremian) of the Isle of Wight. Palaeontographical Society Monographs, 162(631), 1-166.

Calvo, J. O., Porfiri, J. D., \& Kellner, A. W. (2004a). On a new maniraptoran dinosaur (Theropoda) from the Upper Cretaceous of Neuquén, Patagonia, Argentina. Arquivos do Museu Nacional, 62(4), 549-566.

Calvo, J. O., Rubilar-Rogers, D., \& Moreno, K. (2004b). A new Abelisauridae (Dinosauria, Theropoda) from northwest Patagonia. Ameghiniana, 41(4), 555-563.

Canale, J. I., Apesteguía, S., Gallina, P. A., Gianechini, F. A., \& Haluza, A. (2017). The oldest theropods from the Neuquén Basin: Predatory dinosaur diversity from the Bajada Colorada Formation (Lower Cretaceous: Berriasian-Valanginian), Neuquén, Argentina. Cretaceous Research, 71, 63-78.

Canale, J. I., Scanferla, C. A., Agnolín, F. L., \& Novas, F. E. (2009). New carnivorous dinosaur from the Late Cretaceous of NW Patagonia and the evolution of abelisaurid theropods. Naturwissenschaften, 96(3), 409-414.

Canudo, J. I., Salgado, L., Barco, J. L., Bolatti, R., \& Ruiz-Omeñaca, J. I. (2004). Dientes de dinosaurios terópodos y saurópodos de la Formación Cerro Lisandro (Cenomaniense superior-Turoniense inferior, Cretácico Superior) en Río Negro (Argentina). Geotemas, 1(68), 31-34.

Carrano, M. T., Benson, R. B., \& Sampson, S. D. (2012). The phylogeny of Tetanurae (Dinosauria, Theropoda). Journal of Systematic Palaeontology, 10(2), 211-300.

Carrano, M. T., \& Hutchinson, J. R. (2002). Pelvic and hindlimb musculature of Tyrannosaurus rex (Dinosauria, Theropoda). Journal of Morphology, 253(3), 207-228.

Carrano, M. T., \& Sampson, S. D. (2008). The phylogeny of Ceratosauria (Dinosauria, Theropoda). Journal of Systematic Palaeontology, 6(2), 183-236.

Casal, G. A., lbiricu, L. M., Álvarez, B. N., Luna, M., \& Martínez, R. D. (2019). Nuevos materiales de Megaraptoridae del Maastrichtiano de la Formación Lago Colhué Huapi, Grupo Chubut, Patagonia Argentina. Publicación Electrónica de la Asociación Paleontológica Argentina, Suplemento Resúmenes, 20(1), R69.

Coria, R. A. (2001). New theropod from the Late Cretaceous of Patagonia. In D. H. Tanke \& K. Carpenter (Eds.), Mesozoic vertebrate life (pp. 3-9). Bloomington \& Indianapolis, Indiana University Press.

Coria, R. A. (2007). Non avian theropods. In Z. Gasparini, L. Salgado, \& R. A. Coria (Eds.), Patagonian Mesozoic reptiles (pp. 229-256). Bloomington \& Indianapolis, Indiana University Press.

Coria, R. A., Chiappe, L. M., \& Dingus, L. (2002). A new close relative of Carnotaurus sastrei Bonaparte 1985 (Theropoda, Abelisauridae) from the Late Cretaceous of Patagonia. Journal of Vertebrate Paleontology, 22(2), 460-465.

Coria, R. A., \& Currie, P. J. (2016). A new megaraptoran dinosaur (Dinosauria, Theropoda, Megaraptoridae) from the Late Cretaceous of Patagonia. PLoS One, 11(7), e0157973.

Currie, P. J., \& Zhao, X. J. (1993). A new large theropod (Dinosauria, Theropoda) from the Jurassic of Xinjiang, People's Republic of China. Canadian Journal of Earth Sciences, 30, 2037-2081.

Delcourt, R., \& Grillo, O. N. (2018). Reassessment of a fragmentary maxilla attributed to Carcharodontosauridae from Presidente Prudente Formation, Brazil. Cretaceous Research, 84, 515-524.

Garrido, A. (2010). Estratigrafía del Grupo Neuquén, Cretácico Superior de la Cuenca Neuquina (Argentina): nueva propuesta de ordenamiento litoestratigráfico. Revista del Museo Argentino de 
Ciencias Naturales nueva serie, 12(2), 121-177.

Gilmore, C. W. (1920). Osteology of the carnivorous Dinosauria in the United States National Museum, with special reference to the genera Antrodemus (Allosaurus) and Ceratosaurus. Bulletin of the United States National Museum, 110, 1-154.

Ibiricu, L. M., Baiano, M. A., Martínez, R. D., Álvarez, B. N., Lamanna, M. C., \& Casal, G. A. (2021). A detailed osteological description of Xenotarsosaurus bonapartei (Theropoda, Abelisauridae): implications for abelisauroid phylogeny. Cretaceous Research, 104829.

Ibiricu, L. M., Casal, G. A., Martínez, R. D., Álvarez, B. N., \& Poropat, S. F. (2020). New materials and an overview of Cretaceous vertebrates from the Chubut Group of the Golfo San Jorge Basin, central Patagonia, Argentina. Journal of South America Earth Sciences, 98, 102460.

Kellner, A. W., Azevedo, S. A., Machado, E. B., Carvalho, L. B. D., \& Henriques, D. D. (2011). A new dinosaur (Theropoda, Spinosauridae) from the Cretaceous (Cenomanian) Alcântara Formation, Cajual Island, Brazil. Anais da Academia Brasileira de Ciências, 83, 99-108.

Lamanna, M. C., Casal, G. A., Martínez, R. D., \& Ibiricu, L. M. (2020). Megaraptorid (Theropoda, Tetanurae) Partial Skeletons from the Upper Cretaceous Bajo Barreal Formation of Central Patagonia, Argentina: Implications for the Evolution of Large Body Size in Gondwanan Megaraptorans. Annals of Carnegie Museum, 86(3), 255-294.

Leanza, H. A., Apesteguía, S., Novas, F. E., \& de la Fuente, M. S. (2004). Cretaceous terrestrial beds from the Neuquén Basin (Argentina) and their tetrapod assemblages. Cretaceous $R e-$ search, 25(1), 61-87.

Machado, E. B., Campos, D. D. A., Calvo, J. O., \& Kellner, A. W. (2013). A new Abelisauroid from the Upper Cretaceous of Brazil. Revista mexicana de ciencias geológicas, 30(2), 446-452.

Madsen, J. H. (1976). Allosaurus fragilis: a revised osteology. Utah Geological and Mineral Survey Bulletin, 109, 1-163.

Madsen, J. H., \& Welles, S. P. (2000). Ceratosaurus (Dinosauria, Theropoda): a revised osteology. Utah Geological Survey, 1-80.

Malafaia, E., Gasulla, J. M., Escaso, F., Narvaéz, I., \& Ortega, F. (2020a). An update of the spinosaurid (Dinosauria, Theropoda) fossil record from the Lower Cretaceous of the Iberian Peninsula: distribution, diversity, and evolutionary history. Journal of Iberian Geology, 46(4), 431-444.

Malafaia, E., Gasulla, J. M., Escaso, F., Narváez, I., Sanz, J. L., \& Ortega, F. (2020b). A new spinosaurid theropod (Dinosauria, Megalosauroidea) from the upper Barremian of Vallibona, Spain: Implications for spinosaurid diversity in the Early Cretaceous of the Iberian Peninsula. Cretaceous Research, 106, 104221.

Marsh, A. D., \& Rowe, T. B. (2020). A comprehensive anatomical and phylogenetic evaluation of Dilophosaurus wetherilli (Dinosauria, Theropoda) with descriptions of new specimens from the Kayenta Formation of northern Arizona. Journal of Paleontology, 94(78), 1-103.

Martinelli, A. G., Borges Ribeiro, L. C., Méndez, A. H., Neto, F. M., Cavellani, C. L., Felix, E., da Fonseca Ferraz, M. L., \& Antunes Teixeira, V. D. P. (2013). Insight on the theropod fauna from the Uberaba Formation (Bauru Group), Minas Gerais State: new megaraptoran specimen from the Late Cretaceous of Brazil. Rivista Italiana di Paleontologia e Stratigrafia, 119(2), 205-214.

Martínez, R. D., Giménez, O., Rodríguez, J., \& Bochatey, G. (1986). Xenotarsosaurus bonapartei nov. gen. et sp. (Carnosauria, Abelisauridae), un nuevo Theropoda de la Formación Bajo Barreal. $4^{\circ}$ Congreso Argentino de Paleontología y Bioestratigrafía (pp. 23-31). Mendoza.
Méndez, A. H., Novas, F. E., \& lori, F. V. (2012). First record of Megaraptora (Theropoda, Neovenatoridae) from Brazil. Comptes Rendus Palevol, 11(4), 251-256.

Motta, M. J., Agnolín, F. L., Brissón Egli, F., \& Novas, F. E. (2020). New theropod dinosaur from the Upper Cretaceous of Patagonia sheds light on the paravian radiation in Gondwana. The Science of Nature, 107(3), 1-8.

Motta, M. J., Aranciaga Rolando, A. M., Rozadilla, S., Agnolín, F. L., Chimento, N. R., Brissón Egli, F., \& Novas, F. E. (2016). New theropod fauna from the Upper Cretaceous (Huincul Formation) of northwestern Patagonia, Argentina. New Mexico Museum of Natural History and Science Bulletin, 71, 231-253.

Novas, F. E. (1997). Anatomy of Patagonykus puertai (Theropoda, Avialae, Alvarezsauridae), from the late cretaceous of Patagonia. Journal of Vertebrate Paleontology, 17(1), 137-166.

Novas, F. E. (1998). Megaraptor namunhuaiquii, gen. et sp. nov., a large-clawed, Late Cretaceous theropod from Patagonia. Journal of Vertebrate Paleontology, 18(1), 4-9.

Novas, F. E. (2009). The Age of Dinosaurs in South America. Indiana University Press, Indiana.

Novas, F. E., Agnolín, F. L., Ezcurra, M. D., Porfiri, J., \& Canale, J. I. (2013). Evolution of the carnivorous dinosaurs during the Cretaceous: the evidence from Patagonia. Cretaceous Research, 45, $174-215$.

Novas, F. E., Agnolín, F. L., Rozadilla, S., Aranciaga Rolando, A. M., Brissón Egli, F., Motta, M. J., Cerroni, M., Ezcurra, M. D., Martinelli, A. G., D'Angelo, J. S., Álvarez-Herrera, G., Gentil, A. R., Bogan, S., Chimento, N. R., García-Marsà, J. A., Lo Coco, G., Miquel, S. E., Brito, F. F., Vera, E. I., Pérez Loinaze, V. S., Fernández, M. S., \& Salgado, L. (2019). Paleontological discoveries in the Chorrillo Formation (upper Campanian-lower Maastrichtian, Upper Cretaceous), Santa Cruz Province, Patagonia, Argentina. Revista del Museo Argentino de Ciencias Naturales, 21, 217-293.

Novas, F. E., Ezcurra, M. D., \& Lecuona, A. (2008). Orkoraptor burkei nov. gen. et sp., a large theropod from the Maastrichtian Pari Aike Formation, Southern Patagonia, Argentina. Cretaceous Research, 29(3), 468-480.

Novas, F. E., \& Pol, D. (2005). New evidence on deinonychosaurian dinosaurs from the Late Cretaceous of Patagonia. Nature, 433(7028), 858-861.

Novas, F. E., \& Puerta, P. F. (1997). New evidence concerning avian origins from the Late Cretaceous of Patagonia. Nature, 387(6631), 390-392.

Paulina-Carabajal, A., \& Coria, R. A. (2015). An unusual theropod frontal from the Upper Cretaceous of north Patagonia. Alcheringa: An Australasian Journal of Palaeontology, 39(4), 514-518.

Pol, D., \& Rauhut, O. W. M. (2012). A Middle Jurassic abelisaurid from Patagonia and the early diversification of theropod dinosaurs. Proceedings of the Royal Society B: Biological Sciences, 279(1741), 3170-3175.

Porfiri, J. D., Novas, F. E., Calvo, J. O., Agnolín, F. L., Ezcurra, M. D., \& Cerda, I. A. (2014). Juvenile specimen of Megaraptor (Dinosauria, Theropoda) sheds light about tyrannosauroid radiation. Cretaceous Research, 51, 35-55.

Porfiri, J. D., Valieri, R. D. J., Santos, D. D., \& Lamanna, M. C. (2018). A new megaraptoran theropod dinosaur from the Upper Cretaceous Bajo de la Carpa Formation of northwestern Patagonia. Cretaceous Research, 89, 302-319.

Rauhut, O. W. M. (2003). The interrelationships and evolution of basal theropod dinosaurs. Special Papers in Paleontology, 69, 1213. 
Rauhut, O. W. M. (2005a). Post-cranial remains of 'coelurosaurs' (Dinosauria, Theropoda) from the Late Jurassic of Tanzania. Geological Magazine, 142(1), 97-107.

Rauhut, O. W. M. (2005b). Osteology and relationships of a new theropod dinosaur from the Middle Jurassic of Patagonia. Palaeontology, 48(1), 87-110.

Rauhut, O. W. M., Huebner, T. R., \& Lanser, K. P. (2016). A new megalosaurid theropod dinosaur from the late Middle Jurassic (Callovian) of north-western Germany: Implications for theropod evolution and faunal turnover in the Jurassic. Palaeontologia Electronica, 19, 1-65.

Rauhut, O. W. M., \& Pol, D. (2019). Probable basal allosauroid from the early Middle Jurassic Cañadón Asfalto Formation of Argentina highlights phylogenetic uncertainty in tetanuran theropod dinosaurs. Scientific reports, 9(1), 1-9.

Samathi, A., Chanthasit, P., \& Sander, P. M. (2019). Two new basal coelurosaurian theropod dinosaurs from the Lower Cretaceous Sao Khua Formation of Thailand. Acta Palaeontologica Polonica, 64(2), 239-260.
Sereno, P. C., Martínez, R. N., Wilson, J. A., Varricchio, D. J., Alcober, O. A., \& Larsson, H. C. (2008). Evidence for avian intrathoracic air sacs in a new predatory dinosaur from Argentina. PLoS one, 3(9), e3303.

White, M. A., Benson, R. B., Tischler, T. R., Hocknull, S. A., Cook, A. G., Barnes, D. G., Poropat, S. F., Wooldridge, S. J., Sloan, T., Sinapius, H. K., \& Elliot, D. A. (2013). New Australovenator hind limb elements pertaining to the holotype reveal the most complete neovenatorid leg. PloS one, 8(7), e68649.

doi: 10.5710/PEAPA.25.10.2021.396

Recibido: 2 de septiembre 2021

Aceptado: 25 de octubre 2021

Publicado: 26 de enero 2022
Acceso Abierto Open Access

This work is licensed under 